\title{
INFRARED RADIOFLUORESCENCE (IR-RF) DATING OF MIDDLE PLEISTOCENE FLUVIAL ARCHIVES OF THE HEIDELBERG BASIN (SOUTHWEST GERMANY)
}

\author{
TOBIAS LAUER ${ }^{1,2}$, MATTHIAS KRBETSCHEK ${ }^{2}$, MANFRED FRECHEN ${ }^{1}$, SUMIKO TSUKAMOTO $^{1}$, \\ CHRISTIAN HOSELMANN ${ }^{3}$ and MICHAEL WEIDENFELLER ${ }^{4}$ \\ ${ }^{1}$ Leibniz Institute for Applied Geophysics, Stilleweg 2, 30655 Hannover, Germany \\ ${ }^{2}$ Sächsische Akademie der Wissenschaften zu Leipzig, Quaternary Geochronology Section at Institute of Applied Physics, \\ TU Bergakademie Freiberg, Bernhard-von-Cotta-Str. 4, 09596 Freiberg, Germany \\ ${ }^{3}$ Hessian Agency for Environment and Geology (HLUG), Rheingaustraße 186, 65203 Wiesbaden, Germany \\ ${ }^{4}$ Agency for Geology and Mining Rheinland-Pfalz (LGB), Emy-Roeder-Str. 5, 55129 Mainz-Hechtsheim, Germany
}

Received 31 May 2010

Accepted 2 September 2010

\begin{abstract}
The infrared radiofluorescence (IR-RF) dating technique was applied to eight fluvial samples that were collected from two sediment cores at the Heidelberg Basin located near Viernheim and Ludwigshafen in southwest Germany. Based on the IR-RF derived ages of the samples it was possible to establish a chronological framework for the Mid-Pleistocene fluvial deposits of the Heidelberg Ba$\sin$. The results allow us to distinguish between four main periods of aggradation. The lowermost sample taken from $100 \mathrm{~m}$ core depth lead to an IR-RF age of $643 \pm 28$ ka pointing to a Cromerian period of aggradation (OIS 17-16). For the Elsterian it is now possible to distinguish between two aggradation periods, one occurring during the Lower Elsterian period (OIS 15) and a second during the Upper Elsterian period (OIS 12-11). For the so called Upper interlayer (or "Oberer Zwischenhorizont" - a layer of organic-rich and finer-grained deposits), the IR-RF results point to a deposition age of around $300 \mathrm{ka}$, with samples taken directly on top and out of this layer yielding IR-RF ages of $288 \pm 19 \mathrm{ka}$ and $302 \pm 19 \mathrm{ka}$, respectively. Hence, the measured IR-RF ages clearly point to a deposition during the Lower Saalian period (OIS 9-8) whereas earlier studies assumed a Cromerian age for the sediments of the Upper Interlayer based on pollen records and also mollusc fauna. The new IR-RF dataset indicates that significant hiatuses are present within the fluvial sediment successions. In particular the Eemian and Upper Saalian deposits are missing in this part of the northern Upper Rhine Graben, as the $300 \mathrm{ka}$ deposits are directly overlain by Weichselian fluvial sediments. It is obvious that time periods of increased fluvial aggradation were interrupted by time periods of almost no aggradation or erosion which should have been mainly triggered by phases of increased and decreased subsidence of the Heidelberg Basin.
\end{abstract}

Keywords: Infrared Radiofluorescence, Heidelberg Basin, Rhine System, Fluvial archives, Middle Pleistocene.

Corresponding author: T. Lauer

e-mail: tobilauer5@googlemail.com

ISSN 1897-1695 (online), 1733-8387 (print)

(C) 2011 Silesian University of Technology, Gliwice, Poland.

All rights reserved. 


\section{INTRODUCTION}

The fluvial and limnic-fluvial archives of the Upper Rhine Graben (URG) host important information about the fluvial history of the Rhine system and the palaeolandscape development of southwest Germany. The thickest successions of unconsolidated Tertiary and Quaternary fluvial sediments can be found in the Heidelberg Basin, located in the northern URG.

This study is within the framework of Heidelberg Basin Drilling Project (Ellwanger et al., 2005; Gabriel et al., 2008) which intends to obtain detailed information on the structure of the Heidelberg Basin, on basin dynamics as well as on the influence of tectonics and climate forcings on sediment supply. The three drilling sites (Fig. 1) are located at Ludwigshafen-Parkinsel (cores P34 and P35, both with $300 \mathrm{~m}$ drilling depth), Viernheim (350 m drilling depth) and Heidelberg UniNord (cores Uni Nord I and II with $190 \mathrm{~m}$ and $500 \mathrm{~m}$ depth, respectively). The cores have been analysed by a multidisciplinary approach (Gabriel et al., 2008) using methods such as palynology, paleontology, heavy mineral analyses, applied geophysics, sedimentology and palaeomagnetic studies. The facies structure of the sediments as well as palaeobotanical information and mineral components provide important information for the environmental conditions in the past. However, to deliver a chronological framework for the palaeolandscape- and environmental evolution, numerical dating of the sediments is mandatory. Luminescence and infrared radiofluorescence dating have the possibility to determine the time elapsed since the last exposure of mineral grains to daylight (Aitken, 1985,1998; Trautmann et al., 1998; Krbetschek et al., 2000) and hence the time of deposition. This information is very important to bring more light into the complex sedimentation cycles of the Rhine system.

A first coarse-grained quartz OSL chronology was recently provided by Lauer et al. (2010) for the Upper Pleistocene units of the Viernheim core. Based on this chronology it was possible to recognize three aggradation phases for the last glacial (Weichselian) period. The lowermost sample dated by Lauer et al. (2010) derived from $33 \mathrm{~m}$ core depth and yielded a quartz OSL age estimate of $56.2 \pm 6.3 \mathrm{ka}$ based on the minimum age model (MAM3) after Galbraith et al. (1999). If the mean value of all measured equivalent dose $\left(D_{e}\right)$ values is used, it results in a maximum age of $94.2 \pm 10.9 \mathrm{ka}$ for this sample.

In a core depth of $39 \mathrm{~m}$ the quartz OSL signal was already in saturation. We therefore investigated further material, taken between 39 and $100 \mathrm{~m}$ core depth, by measuring the infrared radioluminescence signal of potassium feldspar for age determinations. The saturation dose of the IR-RF is at about 1200-1500 Gy (Erfurt and Krbetschek, 2003a). The method therefore enables to date much older sediments which helps us to further complete the chronological study for Quaternary aggradation periods of the Heidelberg Basin.

\section{GEOLOGICAL SETTING}

Due to the long term subsidence of the Upper Rhine Graben (URG) since the mid-Eocene, very thick Tertiary and Quaternary sediments have deposited and preserved (Bartz, 1974; Cloetingh et al., 2005; Haimberger et al., 2005; Hagedorn and Boenigk, 2008; Preusser, 2008). The source areas of the unconsolidated deposits can be found in the Alps and in the eastern and western Graben margins (for example Buntsandstein-Odenwald, see Fig. 1). The Quaternary deposits of the URG are characterized by different components of heavy minerals if compared to the Tertiary sediments and show a higher carbonatecontent (Ellwanger et al., 2005; Hoselmann, 2008). This can be explained with the connection of the Rhine to the Alpine source areas, which has happened during Pliocene (Kemna, 2005).

The thickest successions of Quaternary deposits should be found in the parts with the highest subsidence rates. In the Heidelberg Basin, Bartz (1974) expected successions of Quaternary deposits being more than 300 $m$ thick. One of the aims of the Heidelberg Basin Drilling Project is to estimate the depth of the PliocenePleistocene boundary and the first results of the project showed that Bartz (1974) even underestimated the thickness of the Quaternary in the northern Rhine Graben. Based on the results of some first pollen spectra, the coring at Heidelberg Uni Nord (basin depocentre) did not reach the Pliocene-Pleistocene boundary at a core depth of $500 \mathrm{~m}$ (Ellwanger et al., 2008). For the Viernheim Drilling site the Pliocene-Pleistocene boundary was found at $225 \mathrm{~m}$ depth (Hoselmann, 2008) and for the

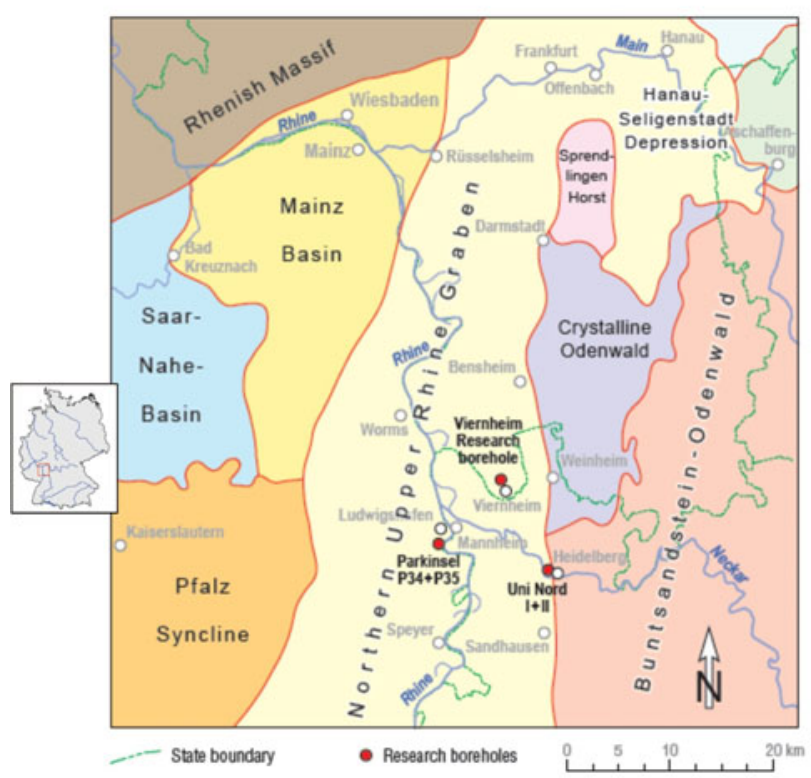

Fig. 1. Study area showing the three drilling sites within the Heidelberg Basin Drilling Project at Heidelberg/Uni Nord, Ludwigshafen Parkinsel and Viernheim (after Gabriel et al., 2008). 
Ludwigshafen drilling sites (P34 and P35) it was found at between 170 and 180 and at $220 \mathrm{~m}$ depth, respectively (Weidenfeller and Knipping, 2008).

From the Ludwigshafen core (P34) the results of the palaeomagnetic study are available (Rolf et al. 2008). The upper $70 \mathrm{~m}$ of sediments show a normal polarity indicating that these sediments correlate with the Brunhes chron. A larger scatter in inclination with reverse and normal polarities within the sediments below $70 \mathrm{~m}$ core depth gives evidence that these sediments had been deposited before the Matuyama/Brunhes polarity change (780 ka).

As mentioned above, Lauer et al. (2010) investigated the upper sediment records of the Viernheim core up to $33 \mathrm{~m}$ by OSL dating. The results showed that these fluvial sediments had been deposited during the Weichselian and were accumulated in different aggradation periods interrupted by phases of fluvial erosion consequently leading to clear chronological gaps between the different units. It can be assumed that the interplay between deposition and erosion is controlled by tectonic subsidence which provides a space for the sedimentary input and by climatic variations which determine the transport dynamics of the Rhine system. Lauer et al. (2010) found that the Weichselian aggradation periods correlate with phases of increasing temperatures (cold to warm transitions) inducing an increase of sediment supply.

Between these coarser-grained upper fluvial units and the finer-grained and organic rich Upper Interlayer ("Oberer Zwischenhorizont”), a clear hiatus was expected. Knipping (2008) investigated pollen assemblages from this layer, and concluded that this layer cannot be correlated with the Eemian interglacial. Following the pollen contents as well as the molluscs identification (Rähle, 2005; Wedel, 2008), a Cromerian age was suggested for the Upper Interlayer. Absolute dating was however necessary to confirm this assumption and provide a more precise chronological framework.

\section{PRINCIPLES OF LUMINESCENCE AND IN- FRARED RADIOFLUORESCENCE DATING}

The methods of luminescence and infrared radiofluorescence dating are based on similar physical processes because both use mineral grains as natural dosimeters. In this section, we describe the basic background of these methods.

Minerals like quartz or potassium feldspars can be used as natural dosimeters. Following the energy band model electrons are lifted from the valence band (VB) up to the higher energetic conduction band (CB) while the minerals are exposed to ionizing radiation (Aitken, 1985). The electrons either recombine directly with connected holes or are trapped in defect structures (traps) located below the CB. The number of occupied traps increases with burial time. The electrons are detrapped again when the mineral is exposed to heat or light (bleaching or zero- ing). During the recombination, the emission of photons occurs (= luminescence).

The datable age range for optically stimulated luminescence (OSL) is thought to be restricted by the quantity of luminescence centres. The OSL signal of quartz reaches to saturation at about 300 Gy (Wallinga, 2002) which covers an age range up to about $150 \mathrm{ka}$ if the dose rate is at $\sim 2 \mathrm{~Gy} / \mathrm{ka}$. Feldspar saturates at much higher doses and hence, the mineral can be used to date much older sediments by infrared stimulated luminescence (IRSL) dating.

One disadvantage of applying IRSL to potassium feldspar is the phenomenon of anomalous fading (Wintle, 1973; Vasil'chenko et al., 2005). The fading rate has to be quantified (Huntley and Lamothe, 2001; Kars et al., 2008) to avoid an age underestimation but this is still problematic especially for older samples showing nonlinear dose response curves.

Infrared Radiofluorescence (IR-RF, also knows as infrared radioluminescence) provides an alternative possibility to date K-feldspar (Trautmann et al., 1999b). Various studies showed that this method is a powerful tool to date sediments from the last glacial-interglacial cycles (Krbetschek et al., 2008). The IR-RF is based on the emission of fluorescent light in the wavelength range of 865nm (Erfurt and Krbetschek, 2003a) occurring during the irradiation of the K-feldspar grains (Trautmann et al., 1998). The emission is linked to the process of electron trapping (Fig. 2) and derives most likely from electron transitions in $\mathrm{Pb}^{+}$centres (Erfurt, 2003).

The intensity of the IR-RF signal correlates with the amount of free optically active traps. The process is therefore independent from recombination phenomena (Krbetschek et al., 2000) and the density of free traps can be measured. The radioluminescence signal decreases

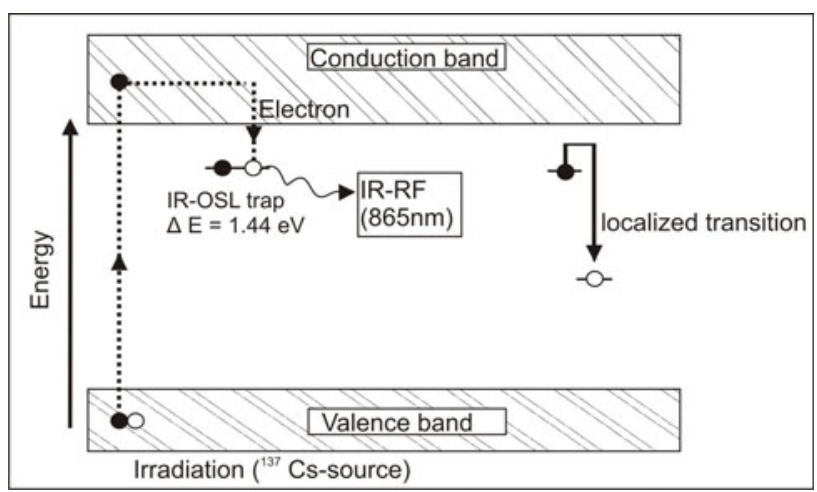

Fig. 2. Two term energy band model explaining the principle of IR-RF (modified after Erfurt and Krbetschek, 2003a). The characteristic fluorescence light emission at $865 \mathrm{~nm}$ is linked to an electron transition into the IR-OSL trap (trapping). The IR-RF is therefore independent from recombination centres. This electron transition is going via the conduction band (CB) whereas the IRSL is linked to a localized transition in which the electron is recombining with a neighbouring recombination site, but not via the CB (Trautmann, 2000). 
with irradiation time whereas it is growing when the material is exposed to daylight. For old samples which are closed to saturation, the detectable natural IR-RF signal is therefore dim (contrary to the OSL signal). Trautmann et al. (2000) found out that the physical process for the IR-RF, regarding the interaction of free electrons and electron traps, are different from the kinetic properties for the IRSL. Whereas the IRSL signal can be bleached by IR-light exposure $(880 \mathrm{~nm})$, the IR-RF signal is only increased by exposing the sample material to higher energy light $(<500 \mathrm{~nm} ;>2.5 \mathrm{eV})$. To explain this phenomenon Trautman et al. (2000) introduced a modified energy level model assuming a localised transition of electrons during IR-light exposure (see also Templer, 1986). Following this model, the electrons are only exited into a higher energetic level during IR-stimulation but not lifted into the CB. However, the IR-RF emission should derive from the electron transition via the $\mathrm{CB}$ into the IRRF trap.

\section{SAMPLING}

Five samples for IR-RF dating were taken from the Viernheim core (samples VH-RF I - V) and further three samples from the Ludwigshafen core (samples LH-RF I III). The sampling positions are marked in Fig. 3 and a more detailed description of the sampled fluvial units of the Viernheim core (Hoselmann, 2008) is provided in Table 1.

From the Viernheim core material for IR-RF dating was taken out of sandy layers in between $\sim 39.5 \mathrm{~m}$ to $\sim$ $100.5 \mathrm{~m}$ core depth with the intention to obtain the chronological framework for the Upper Interlayer and also for the fluvial units below.

The finer-grained Upper Interlayer is characterized by high contents of organic material (Hoselmann, 2008, see also Table 1 and Fig. 4) and should correlate with a warmer climate period. So far, there were no absolute dating results available for this layer. Therefore one sample (VH-RF I) was taken from directly above the finergrained and organic-rich Upper Interlayer (Fig. 4) and one other sample (VH-RF II) from the layer (unit $\mathrm{Xb}$ ) itself. Samples VH-RF III and VH-RF IV were taken from the coarse-grained unit below the Upper Interlayer (unit Xa) and sample VH-RF V from the lower part of unit IXa2 ranging from $77 \mathrm{~m}-101.5 \mathrm{~m}$ core depth (see Fig. 3).

Samples from the Ludwigshafen core (P34) were all taken from sediments below the Upper Interlayer in between $\sim 40.5 \mathrm{~m}-49.5 \mathrm{~m}$ core depth with the aim to figure out if a correlation of the fluvial units from below the Upper Interlayer is possible between the Viernheim and the Ludwigshafen cores.

\section{SAMPLE PREPARATION}

The radioluminescence signal is emitted from Kfeldspars (particularly orthoclase and microcline) and it is therefore important to obtain a high purity of the Kfeldspar extracts for measurements. For mineral preparation the sediment was first dried and sieved to isolate the $100-300 \mu \mathrm{m}$ grain size fraction. Organic matter was removed by $\mathrm{H}_{2} \mathrm{O}_{2}$ treatment. The quartz and heavy mineral fractions were isolated from the feldspars by flotation (Miallier et al., 1983) followed by a separation of the potassium feldspar fraction from other feldspars using sodium polytungstate $\left(2.58 \mathrm{~g} / \mathrm{cm}^{3}\right)$. The $\mathrm{K}$-feldspars were etched using $10 \% \mathrm{HF}$ for $40 \mathrm{~min}$ and $10 \% \mathrm{HCL}$ for 30 min to remove the alpha ray-effected outer rim of the grains. After the etching procedure, the material was resieved to separate the $<90 \mu \mathrm{m}, 90-160 \mu \mathrm{m}$ and $>160$ $\mu \mathrm{m}$ grain size fraction. For measurements either the 90 $160 \mu \mathrm{m}$ or the $>160 \mu \mathrm{m}$ fraction was used.

To check the purity of the K-feldspar extracts, the material was analysed using a raster electron microscope. For all analysed samples a K-feldspar content of $>90 \%$ was obtained. This demonstrates that the flotation technique is a powerful tool for obtaining high quality of feldspar extracts. For sample VH-RF I the mineral separation was first done by just using sodium polytungstate solutions $\left(2.58,2.62\right.$ and $\left.2.70 \mathrm{~g} / \mathrm{cm}^{3}\right)$ without flotation. For this sample the percentage of feldspar grains was at only $\sim 80 \%$.

\section{DOSE RATE}

\section{External dose rate}

The external dose rate was quantified by measuring the contents of the radionuclides uranium and thorium and potassium $\left({ }^{40} \mathrm{~K}\right)$ which are present within the natural sediment. For measurements $50 \mathrm{~g}$ of the material was taken from each sample. The material was first dried and then stored for four weeks to avoid any radon specific disequilibrium. Gamma spectrometry was then carried out on a high purity germanium gamma detector. To obtain the concentrations of uranium, thorium and potassium the activities of ${ }^{238} \mathrm{U},{ }^{232} \mathrm{Th}$ and ${ }^{40} \mathrm{~K}$ were measured (Aitken, 1998).

The water content was estimated to be at $18 \pm 6 \%$. This moisture content was calculated by Lauer et al. (2010) for the upper fluvial units of the Viernheim core and it is based on the assumption that the unconsolidated sediments were water saturated during almost the whole burial period. Due to the fact that there is no big difference in grain sizes between the layers sampled for IR-RF dating and the fluvial sands that were dated by Lauer et al. (2010), the same water content was used. 


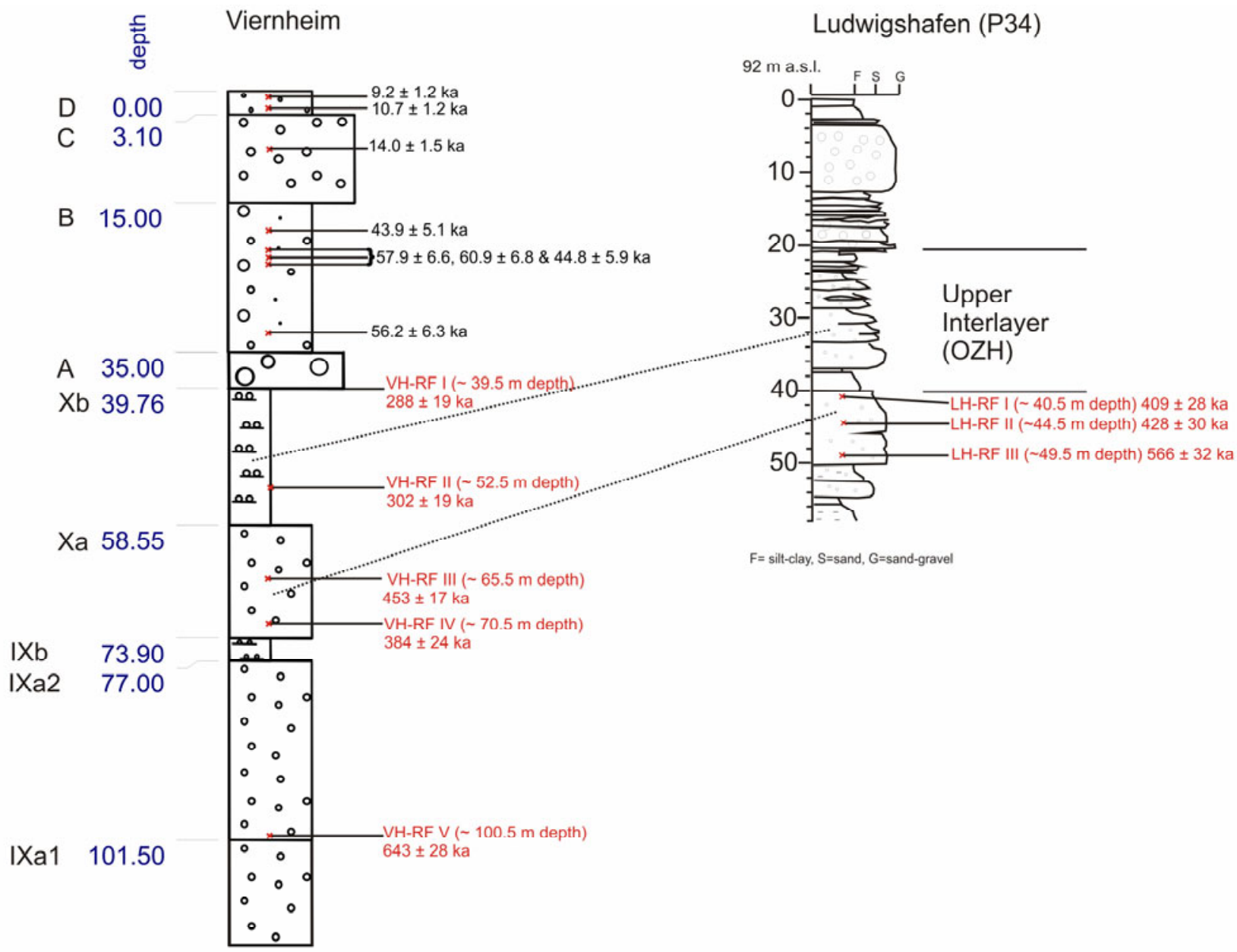

Fig. 3. Viernheim core (left side) and Ludwigshafen core (core P34, right side) modified after Hoselmann (2008) and Rolf et al. (2008), respectively. The IR-RF age estimates are inserted into the graph. The quartz OSL dating results from Lauer et al. (2010) are also inserted into the Viernheim core. The dotted lines mark core sections that can most likely be correlated.

Table 1. Legend to sedimentological units of the Viernheim core after Hoselmann (2008).

\begin{tabular}{|c|c|c|c|}
\hline Unit & $\begin{array}{l}\text { Depth in } m \text { below } \\
\text { ground level }\end{array}$ & Description summary & Special features \\
\hline $\bar{D}$ & $0-3.1$ & Markedly coarse, pedogenically overprinted aeolian sand & $0-1 \mathrm{~m}$ core loss \\
\hline C & $3.1-15$ & $\begin{array}{l}\text { Gravely sands and gravels with fining-upward and coarsening-upward } \\
\text { sequences, Rhenish portion strongly reduced }\end{array}$ & Neckar gravels \\
\hline B & $15-35$ & Four fining-upward sequences, inhomogeneous, $27-32 \mathrm{~m}$ gravel & $\begin{array}{l}\text { With Rhenish Facies in the fine grained } \\
\text { parts, Neckar gravel }\end{array}$ \\
\hline A & $35-39.76$ & $\begin{array}{l}\mathrm{Xb} \text { is discordantly overlain by gravely sands to gravels in three fining } \\
\text { upward sequences }\end{array}$ & $\begin{array}{l}\text { With Rhenish Facies in the fine grained } \\
\text { parts, Neckar gravels }\end{array}$ \\
\hline $\mathrm{Xb}$ & $39.76-58.55$ & $\begin{array}{l}\text { Dominantly fine-clastic with sandy intercalations, partially in Rhenish } \\
\text { Facies, at } 49 \text { and } 53.5 \mathrm{~m} \text { strongly humic, five partial sequences in } \\
\text { total, humic clays and peat in the upper section }\end{array}$ & 51.9-52.5 $\mathrm{m}$ in typical Rhenish Facies \\
\hline Xa & $58.55-73.9$ & $\begin{array}{l}\text { The cycle begins with sand and some gravel, coarsening upwards, } \\
\text { from } 67-69 \mathrm{~m} \text { reddish because of the stronger Neckar influence, then } \\
\text { fluctuating fine gravel portions }\end{array}$ & $\begin{array}{l}\text { Concretionary in part due to calcareous } \\
\text { content }\end{array}$ \\
\hline $\mathrm{IXb}$ & $73.9-77$ & $\begin{array}{l}\text { Fine clastic sediments, reduced at the bottom, then humic up to } 75 \mathrm{~m} \text {, } \\
\text { followed by strong humic peat and finally by silt }\end{array}$ & $\begin{array}{l}70-80 \mathrm{~m}, 87.2-88.2 \text { and } 101,8-103 \mathrm{~m} \text { in } \\
\text { typical Rhenish Facies }\end{array}$ \\
\hline IXa2 & $77-101.5$ & $\begin{array}{l}\text { Marked change in colour from grey to more reddish colours up to } 98 \\
\mathrm{~m} \text { Coarsening-upward sequence, from } 88.2 \mathrm{~m} \text { again sediments in } \\
\text { Rhenish Facies, becoming more fine-grained upwards. }\end{array}$ & $\begin{array}{l}\text { Notable colour change IXa2 to IXa1. IXa2 } \\
\text { with strong influence from Neckar sedi- } \\
\text { ments? }\end{array}$ \\
\hline IXa1 & $101.5-122.09$ & $\begin{array}{l}\text { VIIIb is discordantly overlain by sandy zone with subordinate inter- } \\
\text { bedded gravely horizons }\end{array}$ & \\
\hline
\end{tabular}




\section{Internal potassium content}

The internal potassium content of the K-feldspars is an important factor because the internal radioactive decay of potassium contributes to a significant part to the ionisation. For the internal dose rate a potassium content of $12.5 \pm 0.5 \%$ is often used (Huntley and Baril, 1997). But it also has to be taken into account that this value can vary among feldspar types derived from different source

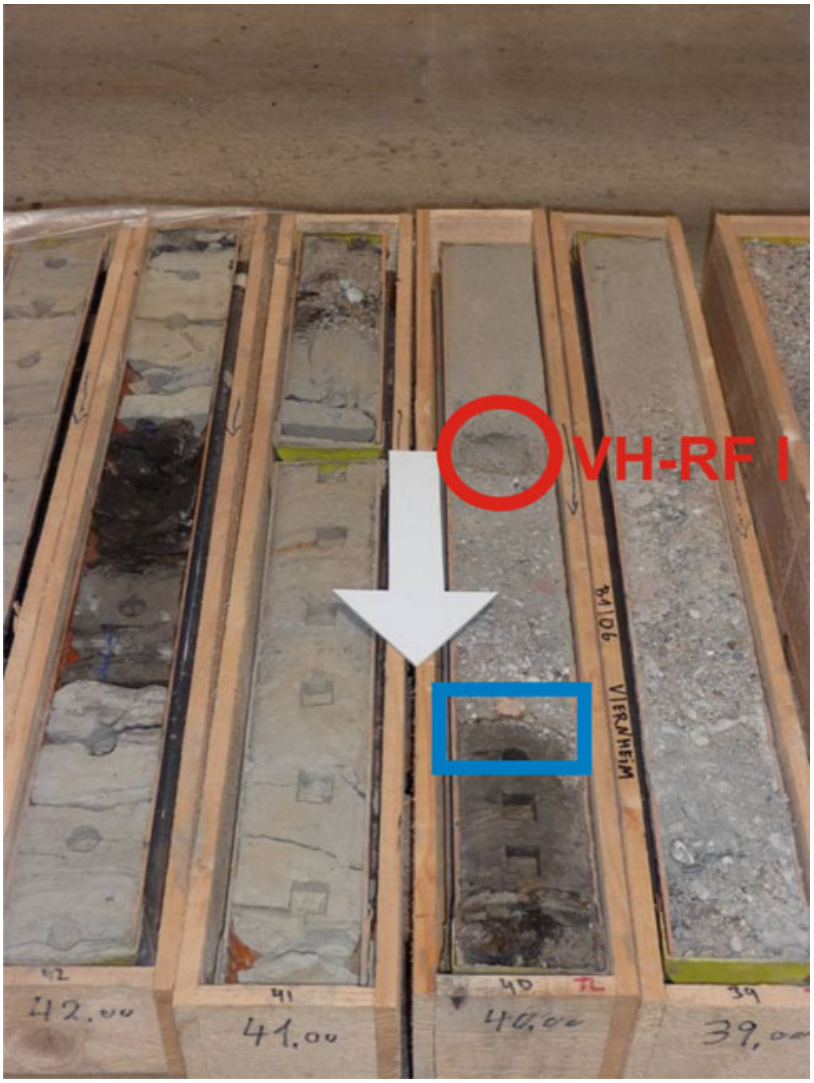

Fig. 4. This photograph shows the core sections of the Viernheim core from $39 m-42 m$ core depth. This core part represents the transition (marked by the bin) from the coarse-grained and gravel rich upper fluvial units and the Upper Interlayer which is characterized by finer material and a high contend of organic material. Sample VH-RF I was taken directly on top of the Upper Interlayer as marked by the circle. areas. To estimate the internal potassium content more accurately, the concentrations of different elements (including K) were measured for all samples from the Viernheim core by electron probe microanalysis. The internal potassium concentrations were measured for 36 to 39 feldspar grains from each sample. For all samples the internal potassium content was calculated by using the mean of all measured internal K-contents from a sample. The error was calculated by the standard error on the mean. For the samples from the Ludwigshafen core (LH-RF I - III) the internal potassium value was estimated by taking the mean of all five values estimated for the Viernheim samples. The values are listed in Table 2.

\section{INFRARED RADIOFLUORESCENCE DATING PROCEDURE}

Measurements were conducted on an automated multi-spectral radioluminesence (RL) instrument, equipped with ten ${ }^{137} \mathrm{Cs}$ sources (Erfurt et al., 2003). For measurements ten aliquots (diameter $=5 \mathrm{~mm}$ ) were used for each sample. The number of measured aliquots was restricted due to the extended length of measurement time. To obtain the $D_{e}$ values, a single-aliquot regenerative-dose dating protocol (IRSAR) was applied (Erfurt and Krbetschek, 2003a). Following the IRSAR protocol, the IR-RF intensity of the natural dose was first measured. After this, the samples were bleached by an mercury lamp. After the relaxation of the phosphorescence which occurs during the bleaching, the natural IR-RF signal was regenerated. The IR-RF was then detected continuously during the irradiation and a few hundreds up to $>1000$ data points were collected. Finally the data points were fitted to a single stretched exponential function (Erfurt and Krbetschek, 2003b) and the natural IRRF signal was interpolated into the curve to obtain $D_{e}$ (Fig. 5).

Table 2. Overview about dosimetry and IR-RF ages: The nuclide concentrations of ${ }^{40} \mathrm{~K}$, Th and $U$ within the sampled material as well as the internal potassium content of feldspar samples define the total dose rate.

\begin{tabular}{|c|c|c|c|c|c|c|c|c|}
\hline Sample & Depth (m) & $\% \mathrm{~K}$ & ppm Th & ppm U & Internal K\% & $\begin{array}{c}\text { Total dose rate } \\
(G y / k a)\end{array}$ & ED (Gy) & Age (ka) \\
\hline VH-RF I & $39.36-39.43$ & $1.59 \pm 0.03$ & $5.21 \pm 0.08$ & $1.59 \pm 0.03$ & $13.36 \pm 0.08$ & $2.54 \pm 0.19$ & $732 \pm 27$ & $288 \pm 19$ \\
\hline VH-RF II & $52.39-52.47$ & $1.43 \pm 0.02$ & $8.27 \pm 0.07$ & $2.37 \pm 0.03$ & $13.15 \pm 0.13$ & $2.75 \pm 0.19$ & $829 \pm 22$ & $302 \pm 19$ \\
\hline VH-RF III & $65.37-65.47$ & $1.50 \pm 0.02$ & $3.00 \pm 0.07$ & $0.85 \pm 0.03$ & $12.77 \pm 0.12$ & $2.16 \pm 0.12$ & $977 \pm 38$ & $453 \pm 17$ \\
\hline VH-RF IV & $70.43-70.52$ & $1.45 \pm 0.03$ & $2.85 \pm 0.09$ & $1.01 \pm 0.05$ & $13.27 \pm 0.08$ & $2.16 \pm 0.15$ & $828 \pm 23$ & $384 \pm 24$ \\
\hline VH-RF V & $100.31-100.39$ & $1.45 \pm 0.02$ & $3.16 \pm 0.07$ & $1.05 \pm 0.04$ & $12.66 \pm 0.11$ & $2.22 \pm 0.12$ & $1425 \pm 43$ & $643 \pm 28$ \\
\hline LH-RF I & $40.44-40.55$ & $1.21 \pm 0.02$ & $3.39 \pm 0.06$ & $1.12 \pm 0.03$ & $13.04 \pm 0.14$ & $2.23 \pm 0.17$ & $911 \pm 31$ & $409 \pm 28$ \\
\hline LH-RF II & $44.50-44.70$ & $1.27 \pm 0.02$ & $3.22 \pm 0.06$ & $1.08 \pm 0.03$ & $13.04 \pm 0.14$ & $2.26 \pm 0.18$ & $966 \pm 37$ & $428 \pm 30$ \\
\hline LH-RF III & $49.40-49.56$ & $1.24 \pm 0.01$ & $2.99 \pm 0.03$ & $0.91 \pm 0.01$ & $13.04 \pm 0.14$ & $2.55 \pm 0.18$ & $1442 \pm 63$ & $566 \pm 32$ \\
\hline
\end{tabular}




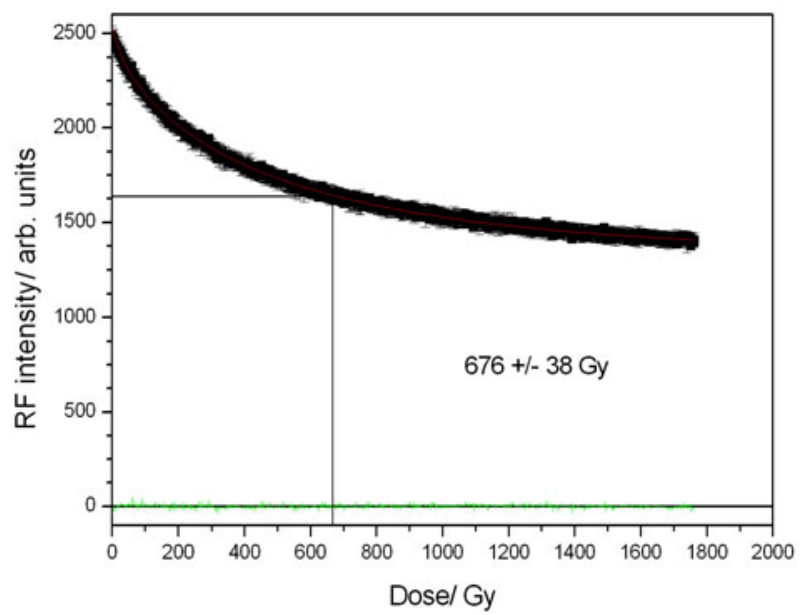

Fig. 5. Response of the IR-RF signal to irradiation (sample VH-RF I). The signal is decreasing with irradiation time. A stretched exponential function was fitted to the IR-RF data (red line). The green line marks the residual of the IR-RF dose curve.

\section{RESULTS}

\section{Dose distribution and statistical treatment}

Fig. 6 shows representative $D_{e}$ distributions from samples VH-RF II and VH-RF III. The scattering among equivalent doses can be explained by a methodological error and incomplete bleaching of some of the grains due to insufficient light exposure during transportation ( $\mathrm{Ar}-$ nold et al., 2007; Jain et al., 2004; Rodnight, 2008). The latter has to be regarded as very likely as it is known that the IR-RF signal is less light sensitive than the IRSL signal. Trautmann et al. (1999a) tested the bleaching behaviour of the IR-RF signal and found out that 2-3 hours of daylight exposure are needed for the radioluminescence signal to reach to the maximum level. Furthermore, Lauer et al. (2010) showed skewed $\mathrm{D}_{\mathrm{e}}$ distributions

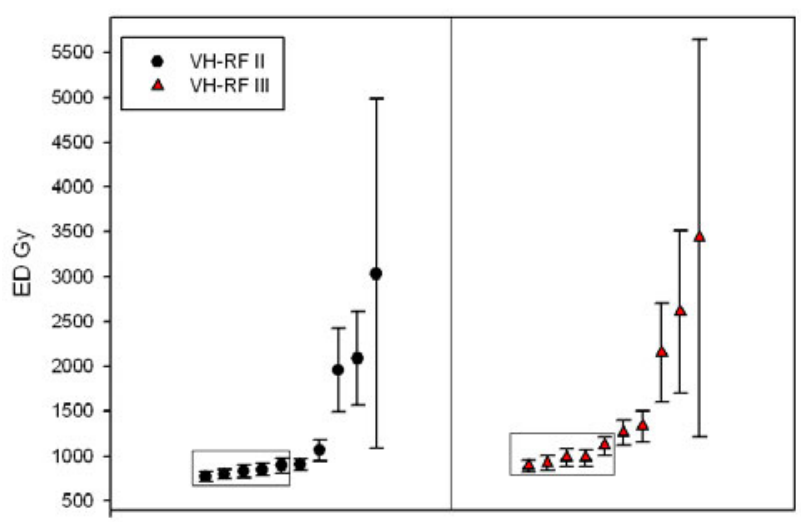

Fig. 6. Distributions of measured equivalent doses from samples $\mathrm{VH}$ RF II and VH-RF III. The values inside the back boxes were included for age calculations following the statistical method described in chapter 8 . from quartz OSL measurements for the samples derived from the upper fluvial units of the Viernheim core. Hence, incomplete bleaching is very likely for the investigated samples and statistical treatment of the data is required.

Due to the small number of available $\mathrm{D}_{\mathrm{e}}$ values (10 aliquotes), the application of statistical models like the minimum age model (Galbraith et al., 1999) or the leading edge method after Lepper and McKeever (2002) was not possible. Therefore we decided to apply a simple statistical treatment to exclude outliers among $D_{e}$ values in the high range. For age calculations, all $D_{e}$ values being equal or less than the median $D_{e}$ values were included. The mean value of these integrated $D_{e}$ values was finally taken for age calculations and the $D_{e}$ error was defined by the standard error on the mean.

\section{IR-RF ages and stratigraphic interpretation}

The IR-RF ages of the Viernheim core and Ludwigshafen core are shown in Figs. 3, 7 and 8 and Table 2. Based on these results four main Middle Pleistocene periods of aggradation have been recognized:

- $\quad$ The IR-RF ages from samples VH-RF I (288 $\pm 19 \mathrm{ka})$ and VH-RF II ( $302 \pm 19 \mathrm{ka}$ ) both point to a deposition of the Upper Interlayer during an early Saalian stage (OIS 9-8). The discrepancy between these ages and so far existing biostratigraphy based on pollen data and molluscs is discussed in chapter 9 .

- A second aggradation period is indicated by the IRRF ages from samples LH-RF I and LH-RF II (Ludwigshafen site), and sample VH-RF IV (Viernheim site). All samples give a statistically equal IR$\mathrm{RF}$ age (409 $\pm 28 \mathrm{ka}, 428 \pm 30 \mathrm{ka}$ and $384 \pm 24 \mathrm{ka}$, respectively) and demonstrate that Upper Elsterian (OIS 12-11) deposits are preserved at both drilling sites. The IR-RF age of sample VH-RF III $(453 \pm 17 \mathrm{ka})$ was not integrated for discussion as it is very likely overestimating the true age maybe due to incomplete bleaching.

- A few metres below LH-RF II, the sample LH-RF III yields a Lower Elsterian age of $566 \pm 32 \mathrm{ka}$ (OIS 15).

- Finally the sample VH-RF V yields a Cromerian age (OIS 17-16, $643 \pm 28 \mathrm{ka}, \sim 100 \mathrm{~m}$ core depth).

These results clearly demonstrate discontinuities within the sedimentation. The main stratigraphical hiatus obviously concerns the Eemian and Upper Saalian, before a recent aggradational period takes place during the Middle Weichselian (Fig. 3, Lauer et al., 2010).

The age difference between samples LH-RF II $(428 \pm 30)$ and LH-RF III (573 \pm 37$)$ also suggests some chronological gap. This gives evidence for a period of sediment erosion during the Lower Elsterian period (most likely OIS 14-13).

Due to the Cromerian age of sample VH-RF V another hiatus may be found with the oldest sediments dated at the Viernheim drilling site. However this hiatus 
may only be due to the lack of dating as $30 \mathrm{~m}$ of sediments separates the samples VH-RF IV and VH-RF V.

\section{DISCUSSION AND CONCLUSION}

A chronology for Middle Pleistocene fluvial deposits from the northern Upper Rhine Graben (Heidelberg Basin) was established using IR-RF dating. It has to be mentioned that only ten aliquots were measured for each sample and the obtained $\mathrm{D}_{\mathrm{e}}$ distributions showed a clear scattering but the values were concentrated in the lower range. Therefore the application of a simple statistical method was mandatory to exclude the higher outliers and to obtain age estimates without clearly overestimating the true age. Based on this procedure it was possible to establish a chronology for Middle Pleistocene fluvial sediment units up to ca $650 \mathrm{ka}$.

\section{Chronology of the Upper Interlayer}

The IR-RF samples which were taken at the Viernheim drilling site to frame the sedimentation age of the Upper Interlayer (VH-RF I and VH-RF II) are in good agreement to each other, yielding an age of $\sim 300 \mathrm{ka}$ (OIS 9-8). Sample VH-RF I, taken directly on top of the Upper Interlayer is at $288 \pm 19 \mathrm{ka}$ and the IR-RF age from sample VH-RF II, taken directly from this layer, is at $302 \pm 19 \mathrm{ka}$. A Holsteinian age for this layer should be

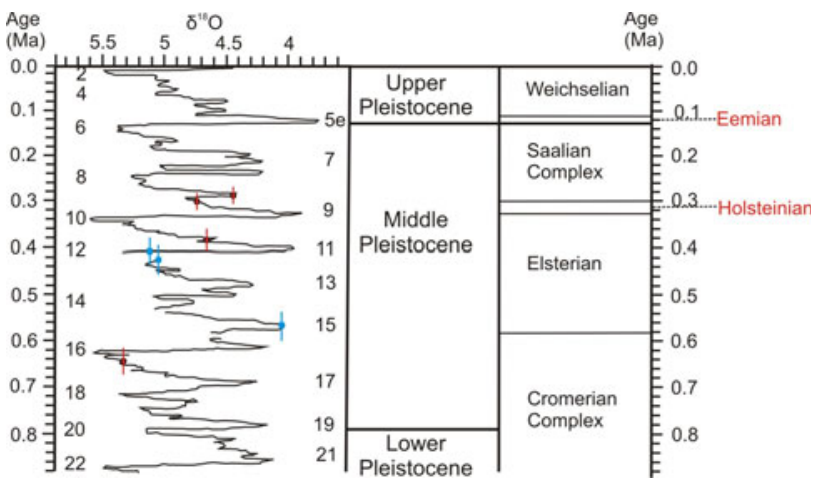

Fig. 7. Marine Isotope record with plotted IR-RF ages from samples VH-RF I, II, IV \& V (red dots) and samples LH-RF I-III (blue squares). The IR-RF age from sample VH-RF III was not inserted because it is most likely overestimating the true age. The Isotope record graph was taken out of Litt (2007) and the shown chronostratigraphy is based on the chronostratigraphical table of Hesse established by the Hessian Agency for Environment and Geology (HLUG) and by the Agency for Geology and Mining Rheinland-Pfalz (LGB).

It is important to underline that the discussions on the chronology of the dated fluvial units follow this chronostratigraphical tables but there are different interpretations in literature about the chronological framework of the Cromerian.

Following the here used tables, the Cromerian ends at around $580 \mathrm{ka}$ but Bittmann \& Müller (1996) correlate the youngest warmer stage of the Cromerian with the so called Kärlich-Interglacial (see also Litt et al., 2007) which was dated using Ar/Ar method to 400 ka (Van den Boogard et al., 1989). very unlikely, because until now in the Upper Interlayer, no pollen of Pterocarya could be found and Buxus is only rare (personal communication, Maria Knipping). Based on the IR-RF ages we now can assume a deposition during an early Saalian stage for this layer. This means that there is a discrepancy between the interpretation of the available biostratigraphical information based on pollen and molluscs (Rähle, 2005; Knipping, 2008; Weidenfeller and Knipping, 2008; Wedel, 2008) and the IR-RF age estimates. Following pollen contents a Cromerian age (older than OIS 15 if following Fig. 7) of the Upper Interlayer could be assumed as it contains pollen markers from different interglacials (Knipping, 2008) and also the found mollusc fauna (Rähle, 2005; Wedel, 2008) would agree with this interpretation.

On the other hand, a clear age underestimation of the IR-RF ages is very unlikely as the radioluminescence signal is far away from saturation for those samples and it is known that the signal is characterized by a high stability what is proven by physical experiments (Erfurt et al., 2000; Trautmann, 2000; Erfurt and Krbetschek, 2003b). If the Upper Interlayer would be Cromerian, the IR-RF ages would underestimate the true age by almost $300 \mathrm{ka}$. This can be excluded due to the described physical characteristics of the IR-RF signal. Furthermore both ages (samples VH-RF I and VH-RF II) point to the same deposition age (OIS 9-8) and if these ages would underestimate the true age that much, also all other here presented IR-RF ages should be affected by the same problem with even increasing tendency for the older samples. This would for example mean that sample LH-RF III (49.5 $\mathrm{m}$ core depth), which yields an IR-RF age of $566 \pm 32 \mathrm{ka}$ (OIS 15), would date to below the BrunhesMatuyama boundary (780 ka). But as mentioned in chapter 2, the upper $70 \mathrm{~m}$ of sediments show a normal polarity for the Ludwigshafen core P34 (Rolf et al., 2008) strongly supporting the assumption that such an age un-

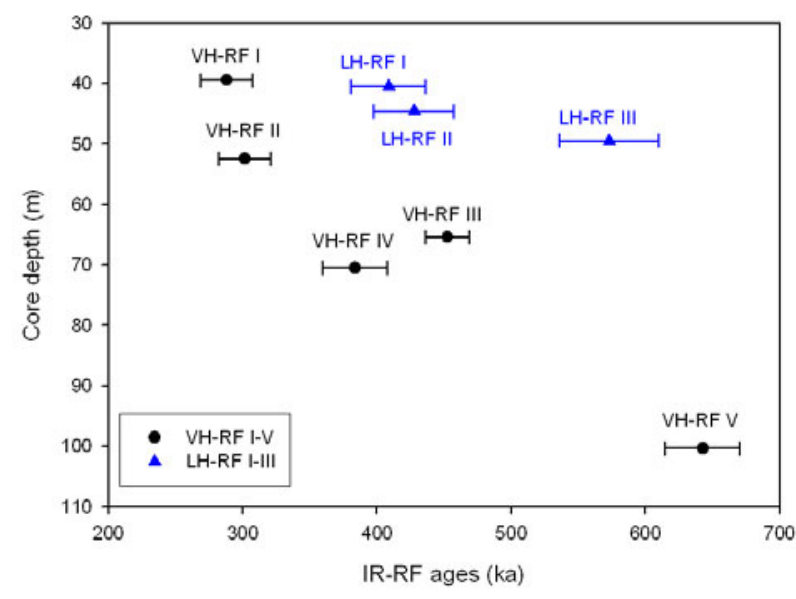

Fig. 8. IR-RF ages plotted against the core depth. 
derestimation of the IR-RF ages is not the case and that the here presented IR-RF data can be regarded as valid. Therefore the question about the chronology of the Upper Interlayer needs further discussions in the future, but following the IR-RF ages a Cromerian deposition age is now very unlikely.

\section{Control mechanisms for fluvial dynamics}

The new chronology can be used for a better understanding of the internal and external forcing on the Rhine fluvial dynamics. When discussing the changes in fluvial dynamics of a huge river system like the Rhine, control mechanisms like sea-level change, climate variations and tectonic activity should be regarded as major forces (Miall, 1996; Roe, 1999; Blum and Törnqvist, 2000; Peters and Van Balen, 2007; Ziegler and Fraefel, 2009). In the case of the Heidelberg Basin, Middle Pleistocene changes in sea level of the North Sea should be regarded as little relevant as the Heidelberg Basin is located relatively upstream. Its fluvial dynamics should hence be driven by tectonic and climate forcing.

The climatic factor can not be neglected as it controls the intensity of fluvial discharge, influences weathering rates and has therefore strong influence on the amount of sediment load. Nevertheless, following the IR-RF ages, the influence of climate cycles is difficult to establish due to the error of the age estimates. Most of the samples may be allocated to cold, warm, or transitional periods. This makes it difficult to discuss this issue but the role of climate was assessed by Lauer et al. (2010) who demonstrated for the younger deposits that fluvial accumulation occurred during the Weichselian periods of warming.

However, it is very likely that for the Middle Pleistocene differences in tectonics play the key role for the preservation of the Rhine fluvial archives. The importance of fault tectonics and variations in subsidence was already demonstrated by Weidenfeller and Kärcher (2008) for the formation of the "Frankenthaler Terrasse" (north-western URG). For the now studied archives near Viernheim and at Ludwigshafen the intensity of subsidence of the Heidelberg Basin should be regarded as the main force controlling the aggradation and preservation of fluvial deposits. Therefore the IR-RF ages can help us to better reconstruct the tectonic history of the Heidelberg Basin. This can be done by having a look on the various mean aggradation rates derived from the chronological data, but when discussing sedimentation rates we have to keep in mind that high resolution dating was not possible and only tendencies for sediment supply in space and time can be deduced. Nevertheless, for the Viernheim core we now can assume an aggradation rate of $\sim 10$ to $14 \mathrm{~m} / 100 \mathrm{ka}$ in between 100 and $70 \mathrm{~m}$ core depth (time period: $643 \pm 28 \mathrm{ka}-384 \pm 24 \mathrm{ka} / /$ OIS $17 / 16$ - OIS 12/11). In between $70 \mathrm{~m}$ and $40 \mathrm{~m}$ core depth (time period: $384 \pm 24 \mathrm{ka}-288 \pm 19 \mathrm{ka} / /$ OIS 12/11 - OIS 9/8) we can assume a much higher about aggradation rate of 22 to $40 \mathrm{~m} / 100 \mathrm{ka}$. It can be assumed that during phases of increased subsidence, aggradation space was created for incoming sediments and relatively complete successions of fluvial archives could be preserved. During phases of only minor or without subsidence, the probability of sediment preservation decreased and climatic controlled erosion consequently caused hiatuses being present in between the fluvial units.

The IR-RF age estimates clearly demonstrate the complexity of the fluvial archives preserved at the Heidelberg Basin which might be explained by small scaled differences in tectonics. It is shown that the successions of Middle Pleistocene fluvial and limnic fluvial sediments are more completely preserved at the Viernheim site than at the Ludwigshafen site (Fig. 8). At Viernheim, the deposits at $\sim 52.5 \mathrm{~m}$ core depth yield an IR-RF age of $302 \pm 19 \mathrm{ka}$ whereas the deposits taken from $\sim 40.5 \mathrm{~m}$ core depth at the Ludwigshafen site yielded an IR-RF age of already $409 \pm 28 \mathrm{ka}$.

It is however essential to keep in mind that the fluvial sequence recorded in the URG results from numerous aggradational and erosional periods. It is hence very likely that the Eemian (OIS 5e) and Upper Saalian (OIS 7-6) sediments had been deposited and were eroded afterwards. In particular the fine-grained Eemian sediments should have been eroded during Weichselian, most likely due to a tectonic impulse but also an increase in fluvial dynamics caused by climate change should have contributed to the erosion of those sediments. One explanation for the absence of Upper Saalian deposits might also be that there was only limited aggradation during this time. During the penultimate glaciation (Saalian or Riss), the glacier extend reached its maximum in the Alpine foreland and also mountains like the Black Forest were covered with widespread ice sheets (Fiebig et al., 2004). This means that huge amounts of water were bound what might have significantly reduced the fluvial discharge and sediment supply towards the Heidelberg Basin at least during cold seasons. But during melting period, the sediment supply was surely reactivated and hence this cannot be the only reason for the absence of Upper Saalian deposits at the drilling sites.

One further reason for the lack of Upper Saalian fluvial deposits at the drilling sites might be explained by the migration of the Rhine in the wide floodplain of the Rhine Graben. Upper Saalian deposits are not preserved at the drilling sites but could possibly be found at other locations within the northern Rhine Graben due to the palaeo-flow regime of the Rhine. The latter was surely significantly influenced by tectonic movements and it was demonstrated by Hagedorn and Boenigk (2008) for the western Graben area that the Rhine was temporarily absent during Quaternary, most likely during times of increased subsidence of the eastern Graben site (Heidelberg Basin). In return it can be assumed that during times of reduced subsidence of the Heidelberg Basin, the Rhine temporary shifted towards the western Rhine Graben. 


\section{ACKNOWLEDGEMENTS}

We thank Dr. Stéphane Cordier (Département de Géographie, Université Paris Est-Créteil-Val-de-Marne (UPEC) and UMR 8591-Laboratoire de Géographie Physique) for scientific support and discussions on fluvial dynamics. We also thank Esther Schmidt, Alexander Kunz and Toni Reimann from the Leibniz Institute for Applied Geophysics (LIAG) in Hanover for support in gamma spectrometry.

\section{REFERENCES}

Aitken MJ, 1985. Thermoluminescence dating. London, UK Academic Press: 359pp.

Aitken MJ, 1998. Introduction to Optical Dating. Oxford, Oxford University Press: 280pp.

Arnold LJ, Bailey RM and Tucker GE, 2007. Statistical treatment of fluvial dose distributions from southern Colorado arroyo deposits. Quaternary Geochronology 2(1-4): 162-167, DOI 10.1016/j.quageo.2006.05.003.

Bartz J, 1974. Die Mächtigkeit des Quartärs im Oberrheingraben. In: Illies JH and Fuchs K, eds., Approaches to Taphrogenesis vol. 8. Inter-Union-Commission on Geodynamics Scientific Report, Stuttgart, Schweitzerbart: 78-87.

Bittmann F and Müller H, 1996. The Kärlich Interglacial site and its correlation with the Bilshausen sequence. In: Turner $\mathrm{C}$, ed., The early middle Pleistocene in Europe. Balkema: 187-193.

Blum MD and Tornqvist TE, 2000. Fluvial responses to climate and sea-level change: a review and look forward. Sedimentology 47(Suppl. 1): 2-48, DOI 10.1046/j.1365-3091.2000.00008.x.

Cloetingh S, Ziegler PA, Beekman F, Andriessen PAM, Matenco L, Bada G, Garcia-Castellanos D, Hardebol N, De' zes P and Sokoutis D, 2005. Lithospheric memory, state of stress and rheology: neotectonic controls on Europe's intraplate continental topography. Quaternary Science Reviews 24(3-4): 241-304, DOI 10.1016/j.quascirev.2004.06.015.

Ellwanger D, Gabriel G, Hoselmann C, Lämmermann-Barthel J and Weidenfeller M, 2005. The Heidelberg drilling project (Upper Rhine Graben, Germany). Quaternaire 16: 191-199.

Ellwanger D, Gabriel G, Simon T, Wielandt-Schuster U, Greiling RO, Hagedorn EM, Hahne J and Heinz J, 2008. Long sequence of Quaternary Rocks in the Heidelberg Basin Depocentre. Quaternary Science Journal (Eiszeitalter und Gegenwart) 57: 316-337.

Erfurt G, Krbetschek MR, Trautmann T, W. Stolz W, 2000. Radioluminescence (RL) behaviour of $\mathrm{Al}_{2} \mathrm{O}_{3}$ :C-potential for dosimetric applications. Radiation Measurements 32(5-6): 735-739, DOI 10.1016/S1350-4487(00)00052-4.

Erfurt G, 2003. Infrared luminescence of $\mathrm{Pb}^{+}$centres in potassium-rich feldspar. Physica status solidi (a) 200(2): 429-438.

Erfurt G and Krbetschek MR, 2003a. IRSAR - A single-aliquot regenerative-dose dating pro-tocol applied to the infrared radiofluorescence (IR-RF) of coarse-grain K feldspar. Ancient TL 21: 21-28.

Erfurt $\mathrm{G}$ and Krbetschek MR, 2003b. Studies on the physics of the infrared radioluminescence of potassic feldspar and on the methodology of its application to sediment dating. Radiation Measurements 37(4-5): 505-510, DOI 10.1016/S1350-4487(03)00058-1.

Erfurt G, Krbetschek MR, Bortolot VJ and Preusser F, 2003. A fully automated multi-spectral radioluminescence reading system for geochronometry and dosimetry. Nuclear Instruments and Methods in Physics Research Section B 207(4): 487-499, DOI 10.1016/S0168-583X(03)01121-2.

Fiebig M, Buiter SJH and Ellwanger D, 2004. Pleistocene glaciations of South Germany. In: Rose J (ed.), Developments in Quaternary Science 2, Amsterdam, Elsevier: 147-154.

Gabriel G, Ellwanger D, Hoselmann C and Weidenfeller M, 2008. The Heidelberg Basin Drilling Project. Quaternary Science Journal (Eiszeitalter und Gegenwart) 57: 253-260.
Galbraith RF, Roberts RG, Laslett GM, Yoshida H and Olley JM, 1999 Optical dating of single and multiple grains of quartz from Jinmium Rock Shelter, northern Australia: Part 1, experimental design and statistical models. Archaeometry 41(2): 339-364, DOI 10.1111/j.1475-4754.1999.tb00987.x.

Hagedorn EM and Boenigk W, 2008. The Pliocene and Quaternary sedimentary and fluvial history in the Upper Rhine Graben based on heavy mineral analyses. Netherlands Journal of Geosciences Geologie en Mijnbouw 87(1): 21-32.

Haimberger R, Hoppe A and Schäfer A, 2005. High-resolution seismic survey on the Rhine River in the northern Upper Rhine Graben. International Journal of Earth Sciences 94(4): 657-668, DOI 10.1007/s00531-005-0514-z.

Hoselmann C, 2008. The Pliocene and Pleistocene fluvial evolution in the northern Upper Rhine Graben based on results of the research borehole at Viernheim (Hessen, Germany). Quaternary Science Journal (Eiszeitalter und Gegenwart) 57: 286-315.

Huntley DJ and Baril MR, 1997. The K content of the K-feldspars being measured in optical dating or thermoluminescence dating. Ancient TL 15(1): 11-13.

Huntley DJ and Lamothe M, 2001. Ubiquity of anomalous fading in Kfeldspars and the measurement and correction for it in optical dating, Canadian Journal of Earth Sciences 38(7): 1093-1106, DOI 10.1139/cjes-38-7-1093.

Jain M, Murray A and Bøtter-Jensen L, 2004. Optically stimulated luminescence dating: how significant is incomplete bleaching in fluvial environments. Quaternaire 15: 143-157.

Kars RH, Wallinga J and Cohen KM, 2008. A new approach towards anomalous fading correction for feldspar IRSL dating - tests on samples in field saturation. Radiation Measurements 43(2-6): 786790, DOI 10.1016/j.radmeas.2008.01.021.

Kemna HA, 2005. Pliocene and Lower Pleistocene Stratigraphy in the Lower Rhine Embayment, Germany. Kölner Forum für Geologie und Paläontologie 14: 1-121.

Knipping M, 2008. Early and Middle Pleistocene pollen assemblages of deep core drillings in the northern Upper Rhine Graben, Germany. Netherlands Journal of Geosciences - Geologie en Mijnbouw 87(1): 51-66.

Krbetschek MR, Trautmann T, Dietrich A and Stolz W, 2000. Radioluminescence dating of sediments: Methodological aspects. Radiation Measurements 32(5-6): 493-498, DOI 10.1016/S13504487(00)00122-0.

Krbetschek MR, Degering D und Alexowsky W, 2008. InfrarotRadiofluoreszenz-Alter (IR-RF) unter-saalezeitlicher Sedimente Mittel- und Ostdeutschlands. Zeitschrift der Deutschen Gesellschaft für Geowissenschaften 159(1): 133-140.

Lauer T, Frechen M, Hoselmann C and Tsukamoto S, 2010. Fluvial aggradation phases in the Upper Rhine Graben - New insights by quartz OSL dating. Proceedings of Geologists' Association 121: 154-161, DOI 10.1016/j.pgeola.2009.10.006.

Lepper K and McKeever SWS, 2002. An objective methodology for dose distribution analysis. Radiation Protection Dosimetry. Solid State Dosimetry 101: 349-352.

Litt T, 2007. Introduction: Climate, Vegetation and Mammalian Faunas in Europe during Middle Pleistocene Interglacials (MIS 7,9,11) In: Sirocko F, Claussen M, Sánchez Goni MF and Litt T, eds., The climate of past interglacials. Elsevier: 352-358.

Litt T, Behre KE, Meyer KD, Stephan HJ and Wansa S, 2007. Stratigraphische Begriffe für das Quartär des norddeutschen Vereisungsgebietes / Stratigraphical Terms for the Quaternary of the North German Glaciation Area. In: Litt T, ed., Stratigraphie von Deutschland, special issue in Eiszeitalter und Gegenwart 56(1/2): 7-66

Miall AD, 1996. The Geology of Fluvial deposits. Sedimentary Facies, Basin Analysis, and Petroleum Geology. Berlin, Springer: 583 pp.

Miallier D, Sanzelle S and Fain J, 1983. The use of flotation technique to separate quartz from feldspar. Ancient TL 1: 5-6.

Peters G and Van Balen RT, 2007. Tectonic geomorphology of the northern Upper Rhine Graben, Germany. Global and Planetary Change 58(1-4): 310-334, DOI 10.1016/j.gloplacha.2006.11.041. 
Preusser F, 2008. Characterisation and evolution of the River Rhine system. Netherlands Journal of Geosciences - Geologie en Mijnbouw 87 (1): 7-19.

Rähle W, 2005. Eine mittelpleistozäne Molluskenfauna aus dem Oberen Zwischenhorizont des nördlichen Oberrheingrabens (Bohrung Mannheim-Lindenhof). Mainzer Geowissenschaftliche Mitteilungen 33: 9-20.

Rodnight H, 2008. How many equivalent dose values are needed to obtain a reproducible distribution? Ancient TL 26: 3-10.

Roe HM, 1999. Late Middle Pleistocene sea-level change in the southern North Sea: the record from eastern Essex, UK. Quaternary International 55(1): 115-128, DOI 10.1016/S1040-6182(98)00032-9.

Rolf C, Hambach U and Weidenfeller M, 2008. Rock and palaeomagnetic evidence for the Plio-Pleistocene palaeoclimatic change recorded in Upper Rhine Graben sediments (Core LudwigshafenParkinsel). Netherlands Journal of Geosciences - Geologie en Mijnbouw 87(1): 39-48.

Templer RH, 1986. The localised transition model of anomalous fading. Radiation Protection Dosimetry 17: 493-497.

Trautmann T, Krbetschek MR, Dietrich A and Stolz W, 1998. Investigations of Feldspar Radioluminescence: Potential for a new Dating Technique. Radiation Measurements 29(3-4): 421-425, DOI 10.1016/S1350-4487(98)00012-2.

Trautmann T, Krbetschek MR, Dietrich A and Stolz W, 1999a. Radioluminescence dating: a new tool for Quaternary geology and archaeology. Naturwissenschaften 86: 441-444.

Trautmann T, Krbetschek, MR, Dietrich A and Stolz W, 1999b. Feldspar radioluminescence: a new dating method and ist physical background. Journal of Luminescence 85(1-3): 45-58, DOI 10.1016/S0022-2313(99)00152-0.

Trautmann T, Krbetschek MR, Dietrich A and Stolz W, 2000. The basic principle of radioluminescence dating and a localized transition model. Radiation Measurements 32(5-6): 487-492, DOI 10.1016/S1350-4487(00)00119-0.

Van den Boogard C, Van den Boogard P and Schmincke HU, 1989. Quartärgeologisch-tephrostratigraphische Neuaufnahme und Interpretation des Pleistozänprofils Kärlich. Eiszeitalter und Gegenwart 39: $62-86$.

Vasil'chenko V, Molod'kov A and Jaek I, 2005. Tunneling processes and anomalous fading in natural feldspars extracted from quaternary deposits. Journal of Applied Spectroscopy 72(2): 218-223, DOI 10.1007/s10812-005-0058-9.

Wallinga J, 2002. Optically stimulated luminescence dating of fluvial deposits: a review. Boreas 31(4): 303-322, DOI 10.1111/j.15023885.2002.tb01076.x.

Wedel J, 2008. Pleistozäne Mollusken aus Forschungsbohrungen des Heidelberger Beckens. Quaternary Science Journal (Eiszeitalter und Gegenwart) 57: 382-402.

Weidenfeller and Kärcher, 2008. Tectonic influence on fluvial preservation: aspects of the architecture of Middle and Late Pleistocene sediments in the northern Upper Rhine Graben, Germany. Netherlands Journal of Geosciences - Geologie en Mijnbouw 87(1): 3340 .

Weidenfeller M and Knipping M, 2008. Correlation of Pleistocene sediments from boreholes in the Ludwigshafen area, western Heidelberg Basin. Quaternary Science Journal (Eiszeitalter und Gegenwart) 57: 270-285.

Wintle AG, 1973. Anomalous fading of thermoluminescence in mineral samples. Nature 245(5421): 143-144, DOI 10.1038/245143a0.

Ziegler PA and Fraefel M, 2009. Response of drainage systems to Neogene evolution of the Jura fold-thrust belt and Upper Rhine Graben. Swiss Journal of Geosciences 102(1): 57-75, DOI $10.1007 / \mathrm{s} 00015-009-1306-4$. 